\title{
ALIRANPARMALIM DALAM PANDANGAN MAJELIS ULAMA INDONESIA DAN PERSEKUTUAN GEREJA- GEREJA INDONESIA WILAYAH SUMATERA UTARA
}

\author{
Arifinsyah dan Peri Agusti \\ Universitas Islam Negeri Sumatera Utara (UINSU) Medan \\ drarifinsyab63@yahoo.com
}

\begin{abstract}
Abstrak
Aliran Parmalim merupakan kepercayan suku Batak, namun banyak masyarakat beranggapan bahwa aliran ini adalah aliran Pemuja Setan (Sipelebegu). Tulisan ini menggunakan metode kualitatif-deskriptif, dan berupaya mengenal aliran parmalim menurutpandangan Majelis Ulama Indonesia serta Persekututan Gereja-gereja di Sumatera Utara. Aliran Parmalim berasal dari dua kata yaitu ugamo dan malim. Majelis Ulama Indonesia Wilayah Sumatera Utara (MUI SUMUT) menyatakan bahwa Aliran Kepercayaan Parmalim bukan bagian dari agama.Sementara Persekutuan Gereja-Gereja di Indonesia Wilayah Sumatera Utara (PGI-WSU) menyatakan bahwa aliran Parmalim merupaka suatu aliran kepercayaan di Indonesia namun memiliki pemahaman iman yang sangat jauh berbeda.
\end{abstract}

Kata kunci: MUI, Parmalim, PGI-WSU

\section{Abstrak}

Parmalim is a Batak tribe belief, but many people assume that this flow is the flow of Satanists. This paper uses a qualitative-descriptive method, trying to recognize the flow of parmalim according to the views of the Indonesian Ulema Council and the Alliance of Churches in North Sumatra. Parmalim flow comes from two words namely ugamo and malim. The Indonesian Ulema Council of North Sumatra Region (MUI SUMUT) states that beliefs Parmalim are not part of religion. While the Alliance of Churches in Indonesia in the North Sumatra Region (PGI-WSU) states that the Parmalim school is a school of belief in Indonesia but has a very different understanding of faith.

Keyword : MUI, Parmalim, PGI-WSU.

\section{Pendahuluan}

Indonesia adalah negara yang terdiri dari berbagai suku bangsa dan bahasa. Kemajemukan dan Pluralisme yang ada di masyarakat Indonesia telah membentuk berbagai macam kebudayaan dan falsafah hidup masyarakat Indonesia (Nicola, 2007 : 4).Kemajemukan tersebut jika dikelola 
dengan baik akan menjadi aset atau modal sosial untuk memperkuat kerukunan, harmonisasi, persatuan dan kesatuan serta kebesaran agama (Hakim, $2005: 1$ ).

Indonesia merupakan bangsa yang religius. Hal tersebut tercermin baik dalam kehidupan bermasyarakat maupun dalam kehidupan bernegara.Agama diyakini sebagai wahyu Tuhan yang menjadi pedoman manusia menjalani kehidupannya, dan suatu kebenaran yang tidak dapat dipungkiri. Sedangkan tindakan manusia meyakini agama dalam bentuk apa pun merupakan realitas sejarah yang tidak dapat diragukan lagi (Arifinsyah, 2018 : 22). Sejatinya, agama dalam kehidupan manusia berkaitan dengan pencarian makna hidup, atau bagaimana seharusnya manusia memaknai hidup (Arifinsyah, $2016: 15)$.

Setiap agama mempunyai dasar teologisnya sendiri untuk mengklaim kebenarannya masing-masing. Sedangkan manusia yang menyampaikan ajaran agama itulah yang memberikan interpretasi. Oleh karena itu, interpretasi manusia atas wahyu menjadi kebenaran yang tidak absolut(Thalhan, 2005 : 273). Begitu halnya banyak tokoh yang mengemukakan beberapa teori asalusul religi (Agus, 2009 : 1).

Di Indonesia selain dari 6 agama yang diakui dalam Ketetapan Presiden Nomor 5 Tahun 1969,juga masih banyak aliran kepercayaan. Sumatera Utara merupakan salah satu Provinsi di Indonesia yang wilayahnya dihuni oleh beragam etnik. Adanya keragaman etnik tersebut mengakibatkan munculnya keragaman adat dan budaya (Djamaluddin, 2011 : 1). Namun tidak hanya adat dan budaya yang beragam, sejalan dengan perkembangan-perkembangan adat dan budaya ini justru memicu masyarakat untuk melakukan ritual, ibadah, dan cara beragama yang baru, dan itulah yang disebut dengan timbulnya aliran kepercayaan baru.

Salah satu aliran tersebut adalah Parmalim, yakni aliran yang tumbuh di Sumatera Utara, yakni alirankepercayaan dan ajaran tradisional Batak, namun banyak masyarakat beranggapan bahwa aliran ini adalah aliran Pemuja Setan "Sipele Begu".Berdasarkan latar belakang di atas, penelitian ini berupaya mengkaji dan menenal aliran Parmalin serta pandangan MUI dan PGIWSU mengenai aliran tersebut.

\section{Pengertian Aliran Parmalim}

Sejak zaman dahulu istilah ugamo atau agama telah dikenal dalam bahasa Batak. Aliran Parmalim berasal dari dua kata yaitu ugamo dan malim. Secara harfiah istilah ugamo bermakna pulungan, atau ambu-ambuan palean (kumpulan atau ramuan dari bermacam-macam benda yang 
dijadikan sebagai palean atau sesaji). Ramuan atau pulungan benda-benda yang dijadikan sesaji itu kemudian disebut dengan ugamo atau agama. Sementara kata malim sendiri bermakna ias (bersih) atau pita (suci).

Parmalim secara etimologis adalah sekumpulan atau sejumlah pulungan atau ramuan benda-benda palean yang bersih lagi suci. Sedangkan menurut istilah aliran Parmalim, ugamo atau agama adalah jalan perjumpaan antara manusia dengan Debata melalui sesaji yang bersih lagi suci (dalam perdomuan ni hajolmaun tu debata marbite pelean na ias). Orang yang masuk dalam aliran Parmalim disebut parugamo malim (pengikut aliran Parmalim) yang sering disingkat dengan parmalim. Parmalim berarti orang yang menuruti ajaran aliran Parmalim atau berkehidupan yang diwujudkan dengan pengumpulan ramuan benda-benda palean (sesaji) berdasarkan pada ajaran Debata Mulajadi Na Bolon. Adapun kata Malim boleh diterjemahkan menurut konteksnya yang bermakna bersih, suci, beriman, beramal, bertakwa, utusan dan termasuk nama aliran Parmalim itu senndiri. (Ibrahim, $2010: 198$ ).

\section{Sejarah Lahirnya Aliran Parmalim}

Sebelum agama Islam dan Kristen datang ke Tanah Batak, orang Batak sudah mempercayai adanya Tuhan Yang Maha Esa yakni Tuhan Debata Mulajadi Na Bolon. Kepercayaan itu diperkirakan telah berlangsung sejak lama yakni sejak si Raja Batak. Tetapi, meskipun kepercayaan Ketuhanan ini telah tumbuh begitu lama dalam masyarakat Batak namun kepercayaan ini belumlah dinamakan sebagai sebuah agama seperti sekarang ini dan mereka masih dalam keadaan tidak beragama (pagan).

Namun, hampir tidak ada satu lingkaran hidup perilakunya yang tidak dibimbing oleh motif religius dan seluruh pemikirannya dikuasai oleh konsep supernatural. Kehidupan keagamaan seperti itu terus hingga sampai masa kepercayaan itu tumbuh menjadi agama pada masa raja Nasiakbagi.

Paganisme orang batak merupakan suatu campuran dari kepercayaan keagamaan kepada Debata, pemujaan yang bersifat animisme terhadap ruh-ruh yang sudah meninggal dunia dan dinamisme. Ketiga unsur keagamaan ini tidak dapat dipisahkan antara yang satu dengan yang lainnya dalam setiap acara adat istiadat (Ibrahim : 77).

Menurut aliran Parmalim, ada empat orang yang tercatat sebagai Malim yang diutus Debata khusus kepada suku bangsa Batak, yaitu Raja Uti, Simarimbulubosi, Raja 
Sisingamangaraja, dan Raja Nasiakbagi. Keempat orang Malim Debata ini diyakini sebagai manusia yang terpilih dari tengah-tengah suku bangsa Batak. Mereka diutus untuk membawa berita keagamaan kepada suku bangsa Batak secara bertahap selama kurun waktu lebih kurang 400 tahun lamanya.

Akan tetapi pada masa Raja Uti, Simarimbulubosi dan Sisingamangaraja, ajaran keagamaan itu belum dibungkus dalam sebutan nama agama. Atau kata lain bahwa ajaran itu belum resmi menjadi sebuah agama. Ia hanya sebuah bentuk kepercayaan yang di dalamnya terdapat amalanamalan (ritual)sebagai sarana tali penghubung antara manusia dengan Debata dan Supernatural lainnya. Semua mereka yang tercatat sebagai Malim Debata itu disebut sebagai orang yang memiliki harajaon malim (kerajaan Malim) di Benua Tonga (bumi) ini. Kerajaan Malim yang mereka pegang itu diyakini dalam aliran Parmalim berasal dari Debata Mulajadi Na Bolon (Ibrahim : 92).

Pada masa Sisingamangaraja XII, penjajah Belanda mulai datang di Tanah Batak. Peperangan berlangsung selama 30 tahun yang disebut dengan Perang Batak. Dalam suatu penyerbuan ke tempat persembunyiannya, Sisingamangaraja XII ditembak mati oleh pasukan Belanda yang dipimpin oleh Christoffel. Pihak belanda mengumumkan bahwa Sisingamangaraja XII telah gugur pada 21 Juni 1907. Akan tetapi menurut kepercayaan aliran Parmalim Sisingamangaraja itu bukanlah mati, karena tidak berapa lama setelah peristiwa penembakan itu, dengan tiba-tiba muncul yang bernama Raja Nasiakbagi yang tersebar di seluruh Tanah Batak. Belakangan dipercayai bahwa yang bernama Raja Nasiakbagi itulah sebenarnya Sisingamangaraja yang diyakini sudah berubah nama.

Tampilnya sosok misterius Raja Nasiakbagi tersebut tentu saja membawa kesan yang menggembirakan bagi masyarakat Batak pada umumnya dan semakin mempertebal keyakinan bahwa raja mereka Sisingamangaraja tidak benar mati. Namun kehadiran sosok yang bernama Raja Nasiakbagi tidak begitu banyak orang mengenalnya, kecuali hanya murid-muridnya. Dia tidak lagi memegang pucuk kekuasaan kerajaan, melainkan hanya memfokuskan diri kepada pembinaan rohani umatnya yang mengajarkan hamalimon (keagamaan). Pada suatu ketika, Raja Naiakbagi memberi arahan kepada murid-muridnya. Dalam pertemuan itu dia berkata: "malim ma hamu” (malimlah kalian). Maksudnya, "sucilah kamu atas senantiasa suci dalam keagamaan”. Dengan adanya pengarahan ini, maka sejak itu pulalah ajaran yang dibawanya resmi dan populer disebut aliran Parmalim. 
Momen pendeklarasian aliran ini sesungguhnya bukan saja bermaksud untuk memantapkan keimanan para pengikutnya, tetapi sekaligus menunjukkan kepada dunia luar terutama kepada agama pendatang bahwa kepercayaan dan ajaran yang diwariskan nenek moyang mereka masih tetap eksis. Seperti dimaklumi pada masa itu, kegiatan kristenisasi sudah semakin gencar dan meluas di tengah-tengah masyarakat Batak. Pada masa itu ada kekhawatiran bagi pengikut aliran Parmalim bahwa kehadiran agama Kristen di Tanah Batak suatu ketika akan mengancam keberadaan dan kelangsungan hidup aliran Parmalim pada masa yang akan datang.

Setelah Nasiakbagi pergi meninggalkan umatnya, aliran Parmalim diwariskan kepada salah seorang murid setianya yaitu Raja Mulia Naipospos. Dia diberikan tugas untuk mempertahankan dan melanjutkan penyiaran aliran Paarmalim (Ibrahim : 95).

Sebagai sebuah komunitas keagamaan lokal yang tumbuh dan berkembang di bagian Selatan provinsi Sumatera Utara, tepatnya di kecamatan Laguboti kabupaten'Toba Samosir, komunitas aliran Parmalim ini dianggap cukup adaptif dengan perkembangan zaman (Katimin, 2012).

\section{Sistem Kepercayaan Aliran Parmalim}

Salah satu unsur dalam struktur agama adalah kepercayaan kepada Tuhan atau kuasa supernatural. Kepercayaan merupakan dasar dalam satu bangunan agama termasuk dalam setiap melakukan ritual keagamaan. Mengingat aliran Parmalim adalah sebuah keyakinan, maka sangatlah penting diuraikan disini tentang sistem kepercayaannya yang mencakup dari semua aspekaspeknya.

1. Kepercayaan Kepada si Pemilik Kerajaan Parmalim (partohap harajon malim) di Banua Ginjang

Secara harfiah istilah Harajaon dalam bahasa Batak sama maknanya dengan kerajaan, sedangkan istilah Partohap bisa diterjemahkan dengan "si pemilik" atau "yang punya bagian". Sementara Parmalim dalam istilah bahasa Batak, selain merujuk pada sebuah alirandi Tanah Batak, malim juga mempunyai makna yang sangat luas. Bergantung kepada konteks pemakaiannya, istilah malim juga bisa berarti bermakna suci dan suruban Debata (nabi).

Selanjutnya yang dimaksud dengan kerajaan Parmalim di Banua Ginjang adalah kerajaan yang ada hubungannya dengan dimensi keagamaan. Menurut aliran Parmalim, sumber wujudnya 
sesuatu agama dapat dipastikan berasal dari si pemilik kerajaan Parmalim yang berkedudukan di Banua Ginjang. Agama apa pun yang ada di bumi ini dipercayai tidak ada satu pun yang tidak berasal dari sana. Oleh karena itu, aliran Parmalim adalah aliran kepercayaan yang khusus diturunkan kepada suku bangsa Batak yang dipercayai bersumber dari Debata Mulajadi Nabolon. Aliran ini diserahkan kepada para Malim Debata (utusan atau nambi) yang berdiam di Banua Ginjang. Dari sanalah semua asal ajaran itu ada yang kemudian oleh malim Debata disampaikan kepada umat manusia di Banua Tonga (Bumi).

Menurut kepercayaan aliran Parmalim, sebelum manusia diciptakan Debata melalui tangan Deakparujar sesungguhnya kerajaan Malim itu sudah lebih dulu ada di Banua Ginjang. Kemudian Debata Menciptakan dewa-dewa lainnya dan mengangkat mereka sebagai pembantunya sekaligus mengikutsertakan mereka dalam barisan si pemilik kerajaan Parmalim di Banua Ginjang. Adapun nama-nama dewa yang dimaksudkan itu ialah Debata Natolu, Siboru Deakparuraj, Nagapadohaniaji dan Siboru Saningnaga.

Perlu diketahui bahwa asas untuk mempercayai semua "si pemilik kerajaan Parmalim di Banua Ginjang" ini bukanlah bersumber dari sebuah kitab suci, melainkan merujuk kepada bunyi tonggo-tonggo (doa-doa) yang disusun oleh Raja Nasiakbagi. Dengan kata lain, melalui doa-doa itulah para penganut aliran Parmalim mengimani dan menjadikannya sebagai referensi dalam melaksanakan berbagai ritual keagamaan.

2. Kepercayaan Kepada si Pemilik Kerajaan Parmalim (partohap harajaon malim) di Banua Tonga.

Dalam kepercayaan aliran Parmalim, ada empat orang yang tercatat sebagai raja atau malim Debata yang sengaja di utus Debata khusus kepada manusia suku Batak, yaitu Raja Uti, Simarimbulubosi, Raja Sisingamangaraja dan Raja Nasiakbagi. Keempat raja ini yang kini merupakan perpanjangan tangan Debata untuk menyampaikan ajaran keagamaan kepada manusia suku Batak dengan maksud supaya mereka berketuhanan (marhadebataon) dan beramal ibadat (marhamalimon). Oleh karena merekalah yang diangkat untuk membawa dan menyampaikann ajaran Parmalim kepada suku Batak, maka mereka pulalah yang disebut sebagai partohap harajaon malim(si pemilik kerajaan Parmalim) di Banua Tonga. Dengan demikian kerajaan Parmalim dapat diartikan kekuasaan dalam hal membina dan mengelolah sebuah agama khusus di Tanah Batak. 
Aliran Parmalim dalam Pandangan Majelis Ulama Indonesia dan Persekutuan Gereja-Gereja

di Indonesia Wilayah Sumatera Utara

Bagi aliran Parmalim, keempat nama malim Debata yang telah disebut diatas semuanya dipercayai sebagai utusan Debata khusus untuk orang Batak. Para Malim Debata itu disebut juga dengan Anak Debatakhusus untuk orang Batak. Makna anak dalam konteks ini adalah todi (ruh) dan ruh inilah yang ditiupkan Debata kepada mereka sehingga sikap dan perilaku mereka berbeda dengan manusia biasa. Yang paling penting lagi ialah mereka bisa memegang amanah dan memiliki kemampuan dalam menyampaikan ajaran agama kepada umat manusia (Ibrahim : 126).

\section{Kepercayaan Kepada Habonaran}

Secara harfiah, kata habonaron dalam bahasa Batak bisa bermakna "kebenaran”.Namun pemahaman dari segi kepercayaan, kata "habonaron" ini belum tepat jika diartikan dengan "kebenaran" karena ia mengandung makna yang sangat luas. "babonaron” adalah kata benda yang berasar dari kata sifat bonar, yang bermakna "benar" sedangkan kata mambonarbon adalah kata kerja yang bermakna "membenarkan".

Dalam budaya Batak merupakan hal yang biasa dan lazim meminjam atau menggunakan kosakata bahasa Batak terutama "kata sifat" atau "kata kerja" yang bermakna positif untuk memberikan nama seseorang anak, misalnya nama tigor (lurus) dan hasudungan (kesenangan hati) dan sebagainya. Akan tetapi dalam konteks ini, istilah babonaron adalah nama yang disebut dengan nama tohonan (jabatan) bagi suruhan Debata yang tugasnya adalah mambonarhon (membenarkan). Artinya si pelaku yang memegang tugas "membenarkan" itu bernama habonaron dan nama ini sesuai dengan tugasnya.

Dalam kepercayaan aliran Parmalim, habonaron adalah berwujud ruh atau tondi. Dia adalah gaib, halus dan zatnya tidak dapat ditangkap oleh panca indera manusia. Meskipun tidak dapat dilihat dengan mata, namun bisa dilihat dengan mata hati (roha) manusia. Bagi aliran Parmalim, babonaron adalah anak naposo (na poso) atau pesuruh (suru-suruan) Debata Mulajadi Nabolon yang bertugas dalam hal mambonarhon segala bentuk perilaku manusia di permukaan bumi ini. Di samping itu ia juga ia bertindak sebagai saksi, menjaga, melindungi (mangaramoti) dan juga memberikan peringatan (pissang-pissang) bagi manusia.

Tugas habonaron dalam hal mambonarhon (membenarkan) adalah semacam legitimasi dan penguatan (reinforcement) dalam hal pekerjaan atau amal manusia. Bentuk tingkah laku yang 
dikuatkan itu bermacam-macam. Ada pekerjaan yang baik dan ada pula yang buruk. Misalnya, apabila ada orang memohon melalui sebuah doa, maka babonaron itulah yang "membenarkan" atau menguatkan kepada Debata. Habonaron dapat berbuat demikian karena setiap saat hadir dan melihat gerak-gerik manusia. Dia dapat memantau semua pekerjaan manusia setiap hari. Sekiranya ada manusia berdoa tetapi tidak sesuai dengan amal perbuatannya, maka habonaron disini mempunya peranan yang sangat besar dalam menilainya.

\section{Kepercayaan Kepada Sabala}

Menurut kepercayaan aliran Parmalim,Sahala adalah ruh suci yang bersumber dari Debata Mulajadi Nabolon yang diturunkan melalui Balabulan kepada umat manusia yang terpilih. Oleh karena itu, sahala tidak dapat dipelajari dan juga tidak dapat dipanggil untuk memperolehnya melainkan ia akan datang sendiri (maisolang) pada seseorang manusia tanpa sepengatuan orang yang bersangkutan. Sahala itu ada yang sifatnya menetap tinggal dan ada juga yang hanya singgah sementara pada seseorang.

Wujud sabalaadalah gaib,halus dan tidak dapat ditangkap oleh panca indra manusia dan tidak pula diketahui kapan masuk dan hinggap pada diri manusia. orang yang dihinggapi sabala disebut “marsahala”(yang menpunyai sahala). Jika seseorang disebut marsahala, itu bermakna bawha sahala tadi telah menyatuh dengan jiwa dan badanya. Apabila orang tersebut "berkata"dan"bergerak", maka apa yang dkatakan dan yang digerakannya adalah perkataan dan gerak sahalayang sudah terintegrasi dengan dirinya. Pribadi nya yang asli tidak akan dimunculkan melaikan pribadi sabala. Dan pribadi sabala inilah yang senantiasa mewarnai sikap dan perilaku manusia setiap saatnya (Ibrahim : 192).

Ciri-ciri orang yang sudah marsahala dapat terlihat pada kehidupan sehari-harinya. Biasanya, orang yang dihinggapi sabala, akan terjadi perubahan pada dirinya terutama dari segi sikap dan perilaku manusia tersebut. Dia akan selalu mengawasi drinya dari hal-hal yang dapat merusak dirinya sendiri dan juga orang lain dimana saja pun dia berada. Disamping itu, pada masa-masa tertentu ada juga terjadi perubahan pada paras orang yang bersangkutan, jika wajahnya sebelum tampak biasa-biasa saja, akan tetapi dengan hadirnya sahalaitu pada drinya akan tampak lebih berwibawa karena sudah mendapatkan siraman sinar kharisma. 


\section{Ritual-Ritual Aliran Parmalim}

Setiap agama dan kepercayaan pasti memiliki ritual atau pun upacara-upacara yang rutin dilakukan oleh penganut agama atau kepercayaan tersebut. Termasuk aliran Paralim yang memiliki berbagai macam jenis ritual keagamaan sebagai berikut.

1. Upacara mararisabtu (ibadah mingguan di hari sabtu)

Mararisabtu adalah salah satu upacara agama yang sangat penting dalam aliran Parmalim. Penepatan hari sabtu sebagai hari upacara sendiri yaitu dari sejarah dimana tepat pada hari sabtu atau hari ketujuh, Siboru Deakparujar menggunakan hari sabtu sebagai hari untuk beristirahat (Ibrahim : 222).

2. Upacara martutuaek (hari kelahiran anak)

Martutuaek adalah upacara khusus untuk memandikan anak yang baru lahir atau juga dapat dikatakan sebagai sambutan untuk anak yang baru lahir ke dunia dan juga sebagai bentu syukur kepada Debata (Ibrahim : 129).

3. Upacara pasahat tondi (kematian)

Pasahat tondi berasal dari 2 kata yaitu "pasahat" yang bermakna "menyampaikan" atau "menyerahkan", sedangkan "tondi" berati "ruh". Dengan demikian arti pasahat tondi yaitu menyampaikan atau menyerahkan ruh kepada Debata Mulajadi Nabolon dan berharap orang yang diserahkan (orang meninggal) tersebut diampuni segala kesalahan dan dosadosanya selama hidup di dunia.

4. Upacara mardebata (sembah debata)

Secara harfiah kata mardebata bermakna "menyembah Debata". Sedangkan menurut istilah, makna mardebata adalah upacara penyembahan kepada Debata dengan menggunakan perantara sesajin atau pelean yang dihantarkan dengan bunyi gendang yang disebut gondang sabangunan atau gendang kecapi (gondang hasapi).

5. Upacara mamasumasu (memberkati perkawinan)

Istilah mamasumasu dapat diartikan sebagai "pemberkatan perkawinan". Dalam istilah ilmu antropologi acara ini merupakan upacara yang termasuk dalam upacara krisis (rites crisis), karena seseorang hendak memalui suatu tahapan perjalanan hidupnya yaitu ke gerbang perkawinan. 
Aliran Parmalim dalam Pandangan Majelis Ulama Indonesia dan Persekutuan Gereja-Gereja

di Indonesia Wilayah Sumatera Utara

\section{Pandangan Majelis Ulama Indonesia (MUI)}

Secara umum Majelis Ulama Indonesia (MUI) Wilayah Sumatera Utara memberi pandangan bukan hanya kepada aliran Parmalim tetapi kepada seluruh Aliran Kepercayaan yang ada di Indonesia bahwasanyaMajelis Ulama Indonesia (MUI) Wilayah Sumatera Utara menganggap aliran kepercayaan bukan merupakan bagian dari agama induk (Ardiansyah , 2019).

Majelis Ulama Indonesia (MUI) Wilayah Sumatera Utara mengacu pada penjelasan yang sudah pernah disampaikan Majelis Ulama Indonesia Pusat bahwa yang dapat disebut dengan agama harus memiliki tiga asas. Pertamasebuah agama itu harus memiliki kitab suci, Kedua memiliki suatu ajaran yang memang dibawa oleh Nabi atau seorang utusan, Ketiga sesuatu itu dapat dikatakan sebagai sebuah agama harus memiliki Tuhan yang disembah, Sekretaris Umum Majelis Ulama Indonesia (MUI) Wilayah Sumatera Utara menegaskan lebih lanjut bahwa makna Tuhan disini yaitu Tuhanyang dapat diidentifikasi, misalnya ada yang bisa terlihat dan atau tidaknya namun dapat dijelaskan oleh aliran kepercayaan yang bersangkutan.

Sementara itu dalam pandangan Majelis Ulama Indonesia (MUI) Wilayah Sumatera Utara selama ini bahwa aliran-aliran kepercayaan yang ada ini tidak memenuhi syarat-syarat yang telah dijelaskan sebelumnya, misalnyaAliran Kepercayaan ini tidak memiliki Kitab yang dalam artian Kitab yang memang dikenal oleh masyarakat luas seperti 6 Agama besar yang sudah diakui di Indonesia antara lain Islam, Kristen, Katholik, Hindu, Budhadan Kong Hu Chu(Ardiansyah, 2019).

Jauh sebelum hal ini, pada awalnya Majelis Ulama Indonesia menolak keputusan yang menjadikan dan mengakui aliran kepercayaaan salah satunya yaitu aliran Parmalim sebagai bagian dari agama dikolom Kartu Tanda Penduduk (KTP) dan sampai saat ini juga Majelis Ulama Indonesia tetap pada pendiriannya. Sama seperti penjelasan sebelumnya bahwa Majelis Ulama Indonesia menganggap agama itu berbeda dengan aliran kepercayaan. Meskipun Majelis Ulama Indonesia mengakui adanya aliran kepercayaan tersebut dan juga memahami perbedaanperbedaan, tetapi Majelis Ulama Indonesia tidak dapat menerima jika aliran kepercayaan disandingkan atau bahkan dianggap sama dengan agama. Jika dianalogikan ada seorang tukang gigi dan juga ada Profesor gigi. Profesor doktor ahli tentang gigi tapi ada juga tukang gigi yg pandai membuat gigi palsu. Apakah keduanya sama? Jelas sangat berbeda. 
Majelis Ulama Indonesia memiliki alasan yang kuat dalam hal ini, karena jika aliran kepercayaan yang ada kemudian diakui sebagai agama maka sangat besar implikasi yang akan ditimbulkan. Bisa saja dikemudian hari merekamenuntut harus memiliki direktorat bahkan kantor seperti agama-agama besar sedangkan jumlah aliran kepercayaan sendiri sangat banyak. Maka dari itu perlu dipahami juga bahwa itu merupakan bagian dari hak anak bangsa tapi seharusnya Pemerintah juga berfikir kritis mengenai masalah ini. Jumlah penganut aliran kepercayaan inipernah dipaparkan oleh Majelis Ulama Indonesia Pusat yaitu tidak lebih dari 300.000 jiwa. Apakah kemudian hanya karena jumlah yang tidak seberapa dibandingkan dengan jumlah rakyat Indonesia ini harus mengorbankan yang 200 juta jiwa (Ardianysah, 2019).

Lebih lanjut lagi jika aliran kepercayaan yang ada itu diakui sebagai agama maka akan ada anggaran Kartu Tanda Penduduk (KTP) khusus.Kemudian jika meninggal orang penganutAliran Kepercayaan misalnya si A dengan kepercayaan Darmo Gandul atau kepercayaan aliran Parmalim siapa yang akan mengurus jenazahnya jika di wilayah tempat dia tinggal hanya ada 1 atau 2 orang saja yang menganut aliran kepercayaan yang sama. Seharusnya hal-hal yang seperti ini yang terkadang tidak difikirkan di kemudian hari.

Lebih jelas Sekretaris Umum Majelis Ulama Indonesia (MUI) Wilayah Sumatera Utara merasa bingung, beliau beranggapan apakah di negara Indonesia segala sesuatu itu hanya diputuskan oleh Mahkamah Konstitusi yang 9 kepala itu saja sementara implikasinya sangat besar untuk masa yang akan datang. Ditambah lagi sebenarnya yang menggugat ke Mahkamah Konstitusi (MK) hanya 2 sampai 3 orang saja dan mereka juga bukan bagian dari penganut aliran kepercayaan yang bersangkutan, walaupun mereka hanya menuntuk masalah identitas pada Kartu Tanda Penduduk (KTP) tetapi apakah hanya sebatas tulisan saja? Hal yang dikhawatirkan sebenarnya merujuk pada kepentingan-kepentingan politik sesaat, kepentingan individu tertentu bahkan malah anggaran-anggaran tertentu (Ardiansyah, 2019).

Jika mereka sebagai penganut aliran Parmalim menuntut masalah hak mengapa harus langsung menggugat masalah ini ke Mahkamah Konstitusi (MK), mengapa tidak ke Komisi Nasional Hak Asasi Manusia (Komnas HAM) terlebih dahulu, yang lebih disayangkan mengapa kemudian Mahkamah Konstitusi malah menerima dan menyidangkan masalah yang jika difikirkan lebih jauh lagi kurang bahkan tidak penting seperti ini. Ketukan palu Mahkamah Konstitusi (MK) 
Aliran Parmalim dalam Pandangan Majelis Ulama Indonesia dan Persekutuan Gereja-Gereja

di Indonesia Wilayah Sumatera Utara

itu mulia dan terhormat bahkan sifatnya final dan mengikat, tidak ada banding dengan hukum yang lain.

Oleh karena itu Majelis Ulama Indonesia hanya menyarankan agar tetap 6 agama saja yang sudah diakui dan biarkan aliran kepercayaan ini hidup dan selama ini mereka juga tidak terganggu kemudian biarkan mereka merujuk kepada agama yang paling dekat dengan aliran kepercayaan yang mereka anut (Ardianysah, 2019).

\section{Pandangan Persekutuan Gereja-Gereja di Indonesia (PGI)}

Persekutuan Gereja-gereja di Indonesia Wilayah Sumatera Utara (PGI-WSU) memandang aliran Parmalim dari segi keberagaman Indonesia, karena jika dari segi pemahaman iman tentu sangat jauh berbeda. Tidak hanya terhadap aliran Parmalim saja, tetapi hal serupa juga berlaku untuk semua aliran kepercayaan yang ada di Indonesia, bahwa Persekutuan Gereja-gereja di Indonesia Wilayah Sumatera Utara (PGI-WSU) memandang aliran kepercayaan dari sudut keberagaman Indonesia. Sebagai contoh pada pada tahun 2018 lalu Persekutuan Gereja-gereja di Indonesia Wilayah Sumatera Utara (PGI-WSU) menjadi pembawa acara pada Seminar Agamaagama yang ke 33 dengan tema "Masyarakat Adat; Reclaming, Identitas dan Keindonesiaan" di Parapat, salah satu pembicara yang hadir yaitu dari aliran Parmalim, dalam acara tersebut mereka saling berdiskusi dan tidak ada sedikit pun menyinggung ajaran satu dengan yang lain.

Dalam hal ini Ketua Umum Persekutuan Gereja-gereja di Indonesia Wilayah Sumatera Utara (PGI-WSU) mengatakan "Akidah terjamin, kerukunan terjalin”, beliau menjelaskan bahwa setiap manusia memiliki akidah masing-masing, jadi alangkah baiknya jika saling menghargai dan menganggap mereka sebagai sesama manusia ciptaan Tuhan yang punya hak penuh untuk melakukan ibadah sesuai dengan kepercayaannya. Karena bicara soal Tuhan itu bicara soal hati nurani pribadi.

Persekutuan Gereja-gereja di Indonesia Wilayah Sumatera Utara (PGI-WSU) juga tidak sependapat ketika anak-anak penganut aliran Parmalim di sekolah di daerah-daerah dengan mayoritas Kristen dipaksakan dalam jalur agamanya untuk mengakui Kristen sebagai agama mereka padahal mereka sendiri penganut aliran Parmalim. Persekutuan Gereja-gereja di Indonesia Wilayah Sumatera Utara (PGI-WSU) menganggap itu sebagai sebuah pembodohan. Namun apa 
Aliran Parmalim dalam Pandangan Majelis Ulama Indonesia dan Persekutuan Gereja-Gereja

di Indonesia Wilayah Sumatera Utara

boleh dibuat karena pada saat itu Undang-undang mengatakan bahwa agama itu hanya 6 yaitu Islam, Kristen, Katholik, Hindu, Budha dan Kong Hu Chu, artinya diluar dari keenam agama itu mereka tidak ada atau bahkan tidak dianggap. Tetapi sekarang sudah ada pengakuan terhadap aliran Parmalim (Bishop, 2019).

Ketua Persekutuan Gereja-gereja di Indonesia Wilayah Sumatera Utara (PGI-WSU) juga mengatakan ketika penganut aliran Parmalim yang tadinya menggunakan agama Kristen dalam identitasnya kini sudah kembali kepada komunitasnya yaitu aliran Parmalim. Hal itu merupakan sesuatu yang jauh lebih baik daripada memanipulasi, meskipun dari segi kuantitas penganut Kristen akan berkurang secara otomatis.

Sebagai contoh umat Kristen di Tobasa berjumlah 5000 orang, ternyata 1000 orang dari 5000 orang tersebuat adalah penganut agama Malim, artinya kita sudah memanipulasi. Maka dari itu biarlah mereka bertahan dengan ibadahnya dan masing-masing kita juga sebaliknya. Yang terpenting mereka tidak mengusik kita dan kita juga tidak mengusik mereka. Itulah konteks yang paling utama yang kita harus ditanamkan dalam konteks Indonesia karena kebhineakan Indonesia memang mengajarkan hal yang seperti itu (Bishop, 2019).

Persekutuan Gereja-gereja di Indonesia Wilayah Sumatera Utara (PGI-WSU) juga berpendapat jika Tuhan berkehendak, di Dunia ini tentu bisa hanya ada sebuah agama karena Dia yang maha kuasa. Tetapi Tuhan memberi peluang kepada manusia, soal akarnya berbeda-beda hanya Kristen dan Islam yang akarnya sama sampai kepada Nabi Isa, setelah Nabi Isa baru terjadi perpecahan antara Islam dan Kristen. Tapi tidak dapat dipungkiri bahwa itulah kehendak Tuhan, maka dari itu Persekutuan Gereja-gereja di Indonesia Wilayah Sumatera Utara (PGI-WSU) tidak setuju jika soal agama diatur-atur oleh Negara, seseorang mau menganut Islam, Kristen, Katholik, Hindu, Budha bahkan Kong Hu Chu tidak dapat dipaksakan. Biarlah Tuhan yang menggariskan kita mau kemana. Termasuk penganut aliran Parmalim tersebut.

Persekutuan Gereja-gereja di Indonesia Wilayah Sumatera Utara (PGI-WSU) juga tidak mau ikut campur mengurusi apakah aliran Parmalim itu termasuk agama suku atau agama lain, yang terpenting mereka memiliki suatu aliran kepercayaan yang mereka miliki sendiri, tata cara ibadah sendiri, aturan-aturan mereka juga milik sendiri. Jadi biar saja mereka menjalankan ibadahnya sesuai dengan hati nuraninya. Lagi pula Undang-Undang Dasar (UUD) sudah memberi 
Aliran Parmalim dalam Pandangan Majelis Ulama Indonesia dan Persekutuan Gereja-Gereja

di Indonesia Wilayah Sumatera Utara

peluang untuk mereka dan mereka sudah diakui sebagai aliran kepercayaan dan penganut aliran Parmalim juga tidak mengganggu dan juga tidak mengusik ketentraman kita (Bishop, 2019).

Mengenai agama Kristen yang digunakan oleh penganut aliran Parmalim dalam kolom agama di Kartu Tanda Penduduk (KTP) mereka, Persekutuan Gereja-gereja di Indonesia Wilayah Sumatera Utara (PGI-WSU) sangat menentang keras. Karena itu merupakan sebuah kepalsuan, mereka seolah-olah Kristen padahal mereka hanya menggunakan Kristen untuk melindungi diri mereka sendiri, lebih baik jujur dan tegas jika mereka adalah penganut aliran Parmalim. Karena tidak ada kemiripan sama sekali antara aliran Parmalim dan agama Kristen, jauh sangat berbeda seperti antara Barat dan Timur.

Namun di suatu sisi karena banyaknya pemahaman yang kurang. Terutama Guru-guru sekolah di daerah ketika ada pelajaran agama malah mengajak siswa-siswa penganut aliran Parmalim untuk mengikuti dan pindah ke agama Kristen dalam pelajaran agama, ujian agama Kristen dan belajar agama Kristen, nilainya pun nilai agama Kristen. Seharusnya sekolah merekomendasikan siswa-siswi penganut aliran Parmalim untuk belajar dengan guru atau pun Imam dalam komunitas aliran Parmalim tersebut.Ketua Persekutuan Gereja-gereja di Indonesia juga mengatakan lebih baik berkurang data statistik penganut agama Kristen daripada kita memberikan data palsu.

Aliran Parmalim bukan kepercayaan batak atau pun bukan agama suku melainkan memang suatu aliran khusus yang berdiri sendiri. Hanya saja pemahaman masyarakat selama ini memang mengatakan aliran Parmalim itu adalah alirankepercayaan suku asli orang Batak padahal kenyataannya tidak. Jika aliran Parmalim merupakan aliran kepercayaan suku orang batak seharusnya semua suku Batak menganut aliran Parmalim tetapi ini hanya didaerah tertentu saja walaupun secara etika mereka ada kemiripan, tetapi aliran Parmalim adalah aliran yang berdiri sendiri.

Secara etika aliran Parmalim memang bagus. Hanya saja kebetulan penganut aliran Parmalim itu sebagian ada yang bersuku Batak tetapi sekali lagi tidak termasuk aliran kepercayaan suku melainkan hanya kebetulan saja penganut aliran Parmalim ini sebagian besar bersuku Batak. Kelihatannya memang beda tipis antara nilai-nilai dalam suku Batak dengan penganut aliran Parmalim, tetapi kalau kita dalami lebih lanjut sangat jauh berbeda (Bishop, 2019). 
Aliran Parmalim di Indonesia tidak diberi fasilitas seperti pendidikan, pemakaman dan perkawinan karena penganut aliran Parmalim itu tidak global melainkan hanya di daerah tertentu saja. Maka sebaiknya di wilayah yang terdapat komunitas aliran Parmalim seharusnya diajarkan oleh imam yang ada di dalam komunitasnya. Jika di Sekolah-sekolah dibuat mata pelajaran pendidikan aliran Parmalim maka tidak sesuai jumlah tenaga pendidik dengan jumlah yang akan dididik. Begitu juga pemakaman dan sebagainya. Jadi tidak dapat dikatakan pemerintah seharusnya membuat aturan untuk memfasilitasi semua yang menjadi kebutuhan penganut aliran Parmalim yang penting cukup diakui saja (Bishop, 2019).

\section{Penutup}

Aliran Parmalim berasal dari dua kata yaitu ugamo dan malim. Secara harfiah istilah ugamo bermakna pulungan, atau ambu-ambuan palean (kumpulan atau ramuan dari bermacam-macam benda yang dijadikan sebagai palean atau sesaji). Ramuan atau pulungan benda-benda yang dijadikan sesaji itu kemudian disebut dengan ugamo atau agama. Sementara kata malim sendiri bermakna ias (bersih) atau pita (suci). Dengan demikian secara etimologis pengertian aliran Parmalim adalah sekumpulan atau sejumlah pulungan atau ramuan benda-benda palean yang bersih lagi suci. Sedangkan menurut istilah agama malim, ugamo atau agama adalah jalan perjumpaan antara manusia dengan debata melalui sesaji yang bersih lagi suci (dalam perdomuan ni bajolmaun tu debata marbite pelean na ias).

Pandangan dari kedua lembaga besar umat Islam dan Kristen yaitu Majelis Ulama Indonesia Wilayah Sumatera Utara (MUI SUMUT) dan Persekutuan Gereja-gereja di Indonesia Wilayah Sumatera Utara (PGI-WSU) juga sangat bertolak belakang dalam menanggapi Aliran Kepercayaan di Sumatera Utara khususnya aliran Parmalim sendiri.

Dimana, dari pihak Majelis Ulama Indonesia Wilayah Sumatera Utara (MUI SUMUT) memberikan pandangan kepada aliran kepercayaan secara umum bahwa aliran kepercayaan bukan bagian dari agama induk yang seharusnya sesuatu itu dikatakan agama apabila memenuhi 3 asas, Pertama sebuah agama itu harus memiliki kitab suci, Kedua memiliki suatu ajaran yang memang dibawa oleh Nabi atau seorang utusan, Ketiga sesuatu itu dapat dikatakan sebagai sebuah agama harus memiliki Tuhan yang disembah, Tuhan yang dapat diidentifikasi, misalnya ada yang bisa terlihat dan atau tidaknya namun dapat dijelaskan oleh aliran kepercayaan yang bersangkutan. 
Maka dari itu Majelis Ulama Indonesia Wilayah Sumatera Utara (MUI SUMUT) sangat tidak setuju jika aliran kepercayaan ini dianggap sebagai agama dan malahan dicantumkan dalam kolom agama pada Kartu Tanda Penduduk (K'TP). Seharusnya biarkan saja aliran kepercayaan itu tetap eksis dengan sendirinya tanpa harus mengakomodir semua kebutuhan dari aliran kepercayaan tersebut, karena selama ini tidak ada kendala jika mereka tetap berpegang pada aliran kepercayaan yang dianut.

Sementara Persekutuan Gereja-gereja di Indonesia Wilayah Sumatera Utara (PGI-WSU) memberikan pandangan terhadap aliran Parmalim sebagai suatu aliran kepercayaan dari segi keberagaman Indonesia karena jika dari segi pemahaman iman tentu sangat jauh berbeda. Setiap manusia memiliki akidah masing-masing jadi akan lebih baik jika kita menghargai mereka sebagai penganut aliran kepercayaan dan juga sekaligus sebagai makhluk ciptaan Tuhan yang memiliki hak dan kewajiban yang sama di Indonesia. Hal yang paling penting yaitu Aqidah terjamin, Kerukunan terjalin. Jadi kita tidak berhak untuk mengusik mereka dan mereka juga tidak berhak mengusik kita.

\section{Daftar Pustaka}

A. Hakim, Bashori. Pandangan Pemuka Agama Tentang Urgensi Pengaturan Hubungan Antarumat Beragama Di Indonesia. Jakarta: Puslitbang Kehidupan Keagamaan Badan Litbang dan Diklat Kementrian Agama RI, 2015.

Arifinsyah. Agama Dialogis, Medan, : Perdana Publishing, 2016

Arifinsyah. Ilmu Perbandingan Agama Dari Regulasi ke Toleransi, Medan, : Perdana Publishing, 2018

Arikunto, Suharsimi. Prosedur Penelitian Suatu Pendekatan Praktek, Jakarta, : PT. Rineka Cipta, 2002.

Colbran, Nicola. Tantangan Yang Dihadapi Masyarakat Adat Dalam Mewujudkan Hak Dan Bekepercayan. Yogyakarta: Pusham UII Yogyakarta, 2007.

Data Majelis Ulama Indonesia oleh Dewan Pimpinan Majelis Ulama Indonesia tahun 2018

Data Persekutuan Gereja-gereja di Indonesia oleh PGI-WSU Tahun 2016

Erlangga, Ruri. Ensiklopedia Seni Dan Budaya Nusantara : Sumatera Utara. Bekasi: PT. Mentari Utama Unggul, 2013.

Feby Yudianita, “Tinjauan Yuridis Terhadap Aliran Kepercayaan Dihubungkan Dengan Pasal 29 Ayat 2 UUD 1945”, Skripsi: Fakultas Hukum Universitas Riau, 2015

Gultom, Ibrahim. Agama Malim Di Tanah Batak. Jakarta: Bumi Aksara, 2010

Hasan, Muhammad Tholhah. Islam Dalam Perspektif Sosio Kultural. Jakarta: Lantabora Press, 2005. 
Aliran Parmalim dalam Pandangan Majelis Ulama Indonesia dan Persekutuan Gereja-Gereja

di Indonesia Wilayah Sumatera Utara

Karim, Helmi. Konsep Ijtihad Majelis Ulama Indonesia Dalam Pengembangan Hukum Islam, Pekanbaru: SusqanPress, 1994.

Kartono, Kartini. Pengantar Metodologi riset Sosial, Bandung: Mandar Maju, 1990.

Katimin.Pertumbuhan dan Perkembangan Parmalim di Sumatera tahun1885-Sekarang, Analityca Islamica Journal. Vol. 1, No. 2.

Margono, S. Metode Penelitian Dan Pendidikan, Jakarta: Rineka Cipta, 2004

Mariyat, Akrim. Ajaran Beberapa Aliran Kebatinan, Darussalam Press Gontor-Ponorogo, 1997

Mukti Ali, A. Beberapa Persoalan Agama Dewasa Ini, Jakarta:Rajawali Press, 1987

Munandar, Agus Aris (ed.). Sejarah Kebudayaan Indonesia. Depok: PT. Raja Grafindo Persada, 2009.

Nuryanti Reni dan Peno Suryanto, Penelitian: Sebuab Pengantar Yogyakarta: UKM Penelitian UNY, 2006.

Purba, Djamaluddin. Budaya Etnik-Etnik Sumatera Utara. Medan: Dinas Pendidikan Sumatera Utara, 2011.

Saidurrahman. Nalar Kerukunan Merawat Keragaman Bangsa Mengawal NKRI, Medan, : Perdana Publishing, 2018

Syafaruddin, (ed.). Metodologi Penelitian. Medan : Fakultas Tarbiyah Institut Agama Islam Negeri Sumatera Utara, 2006.

Tata Dasar dan Tata Rumah Tangga Persekutuan Gereja-gereja di Indonesia Wilayah Sumatera Utara Tahun 2018

Wawancara dengan Bapak Bishop Darwis Manurung, S.Th., M.Psi., (Ketua Umum Persekutuan Gereja-gereja di Indonesia Wilayah Sumatera Utara, pada tanggal 29 Mei 2019 di Kantor PGI Wilayah Sumatera Utara, pukul 10.10 Wib.

Wawancara dengan Bapak Dr. H. Ardiansyah, Lc., MA., (Sekretaris Umum Majelis Ulama Indonesia Wilayah Sumatera Utara, pada tanggal 1 Juli 2019 di Kantor MUI Provinsi Sumatera Utara, pukul 13.02 Wib 